\title{
Kaplica grobowa rodziny Trębickich $w$ Zembrowie jako przykład francuskich wpływów $w$ dziewiętnastowiecznym budownictwie sepulkralnym na ziemiach polskich
}

Streszczenie. Kaplica rodziny Trębickich h. Ślepowron powstała w 1884 roku na starym cmentarzu przykościelnym w Zembrowie na Podlasiu (pow. sokołowski). Budowlę wznieśli Stanisław i Emilia Trębiccy, właściciele majątku ziemskiego i murowanego dworu w Kurowicach. Nieznany z imienia i nazwiska architekt nadał wymurowanej z cegły wiśniówki i szarego piaskowca kaplicy formy romańsko-gotyckie, które zaczerpnął z francuskiego czasopisma branżowego „Revue générale de l’architecture et des travaux publics". Za pierwowzór posłużyły opublikowane na jego łamach w 1876 roku plany budowli grobowej arystokratycznej rodziny Berghesów, którą zaprojektował i wzniósł na cmentarzu w Rânes (rejon Normandia, departament Orne) w latach 1872-1873 architekt Victor Ruprich-Robert (1820-1887). Kaplica w Zembrowie jest jedną z wielu polskich budowli grobowych inspirowanych francuskimi realizacjami. Dotychczasowe badania prowadzone przez autorkę wykazały, że statystycznie najwięcej takich obiektów powstało na cmentarzach katolickich w Warszawie (33) i na terenie Królestwa Polskiego (9).

Słowa kluczowe: Zembrów, kaplica Trębickich, polska architektura sepulkralna, francuska architektura sepulkralna

samym centrum Zembrowa - podlaskiej wsi położonej w powiecie sokołowskim, po przeciwnej stronie szosy niż kościół pw. Najświętszego Zbawiciela, znajduje się kaplica grobowa rodziny Trębickich 


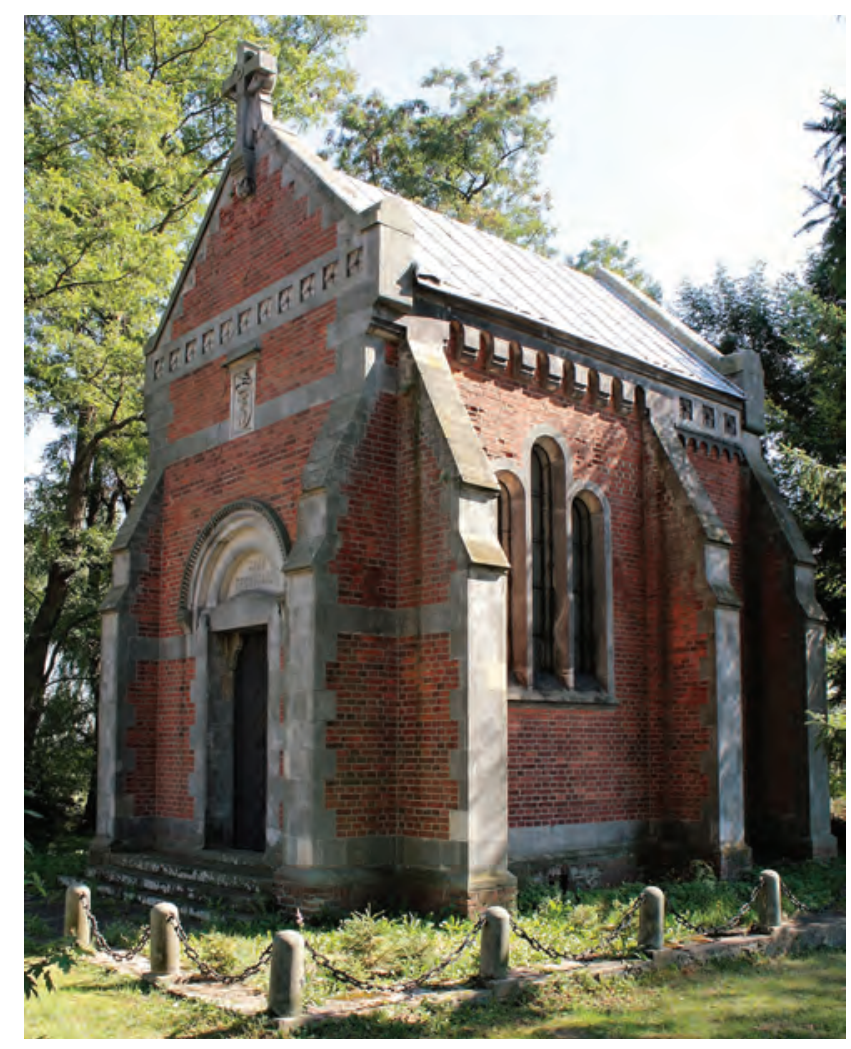

1. Kaplica grobowa Trębickich $w$ Zembrowie - elewacje frontowa i boczna Fot. M. Wiraszka, 2011

- do 1939 roku właścicieli majątku ziemskiego i murowanego dworu w niedalekich Kurowicach. Budowla utrzymana w stylu romańsko-gotyckim stoi na dawnym cmentarzu, który od drogi odgradza, zachowany do dziś, niski kamienny mur z granitowych otoczaków. Do roku 1906 na terenie cmentarza wznosił się osiemnastowieczny kościół drewniany pw. Najświętszej Maryi Panny i św. Jana Chrzciciela ${ }^{1}$, który po wybudowaniu w latach 1902-1905 nowej, murowanej świątyni według projektu Kazimierza Zajączkowskiego - budowniczego powiatu węgrowskiego ${ }^{2}$,

1 Drewniany kościół w Zembrowie był trzecią niemurowaną świątynią wzniesioną w tej miejscowości. Fundacja pierwszego miała miejsce w 1486 r., drugiego w 1525 r., a budowę trzeciego z fundacji Antoniego Ossolińskiego - starosty sulejowskiego i właściciela okolicznych dóbr, ukończono w 1773 r. W 1885 r. kościół został odrestaurowany. Po zbudowaniu murowanego został rozebrany na początku XX w. Jego wygląd dokumentuje fotografia amatorska C. Kleczeńskiego zamieszczona w 1905 r. w „Tygodniu Ilustrowanym” i „Ziarnie”. Podobne do niego budowle zachowały się w Skibniewie Podawcach i Rozbitym Kamieniu. Zob. Zembrów 1895, s. 570; Kronika. Uroczystość..., 1905, s. 764; Nowy kościół..., 1905, s. 308-309; KZSP 1965, s. 32; BARBASIEWICZ 2008, s. 110.

2 Murowana świątynia została wzniesiona z czerwonej cegły w stylu romańsko-gotyckim dzięki ofiarności okolicznych ziemian, głównie Ludwika Górskiego, Emilii hr. Starzeńskiej, 1 voto 
został zburzony, a materiał pozyskany z rozbiórki posłużył do wzniesienia plebanii. Teraz najbliższe otoczenie kaplicy Trębickich tworzą niewielki cmentarz rodowy rodziny Mniszek-Tchórznickich z połowy XIX wieku, na którym pochowano Helenę Mniszkównę, autorkę powieści Trędowata, stara i nowa plebania, ogród z podwórzem oraz wiekowe lipy.

Dojście do kaplicy poprzedza dwuskrzydłowa ażurowa brama metalowa osadzona na ceglanych słupach. Taka sama znajduje się po drugiej stronie drogi, przed wejściem do kościoła. Dodatkowo teren położony wokół budowli grobowej oddziela od obszaru dawnego cmentarza niskie ogrodzenie, składające się z kamiennej podmurówki i ustawionych na niej zaokrąglonych słupków, które połączono metalowymi łańcuchami.

Do budowy kaplicy użyto cegieł wiśniówek oraz szarego piaskowca. Cegła została wykorzystana do konstrukcji ścian wymurowanych w wątku krzyżowym. Kamień natomiast posłużył do oblicowania niektórych powierzchni, np. cokołu, czoła przypór i krawędzi szczytu, oraz wykonania elementów kamieniarki, takich jak obramienia okien i portalu, fryzów, trzystopniowych schodów poprzedzających wejście, prostokątnej płyty z płaskorzeźbioną tarczą herbową czy krzyża wieńczącego szczyt fasady.

Naroża budowli zembrowskiej, postawionej na rzucie prostokąta, zostały ujęte dwuuskokowymi skarpami krzyżowymi. Dodatkowa para przypór, widoczna w elewacjach bocznych, posłużyła do wyodrębnienia wąskiego przęsła ołtarzowego. Analogicznie wewnątrz w tych samych miejscach znajdują się cztery wąskie, prostokątne występy. Kaplicę nakrywa dwuspadowy dach z poszyciem z blachy cynkowej, skrywający się za ścianami szczytowymi. Podstawę obu trójkątnych szczytów i zakończeń przęsła ołtarzowego dekoruje fryz z kasetonowymi płycinami, które wypełnia kolista forma w postaci szerokiego okręgu z nałożonymi na jego powierzchnię klinami w układzie krzyżowym. Pozostałe ściany obiega fryz arkadkowy. Do wnętrza prowadzi portal zamknięty łukiem pełnym, z zewnętrzną archiwoltą ozdobioną ząbkowaniem i wyrytym w tympanonie napisem dedykacyjnym: GRÓB TRĘBICKICH. Nad wejściem znajduje się herb Ślepowron, który widnieje również na dwóch klamkach otwierających drzwi do kaplicy. Budynek jest dwupoziomowy. Dolną kondygnację zajmuje obszerna krypta z katakumbami usytuowanymi pod częścią ołtarzową, dostępna od wnętrza kaplicy przez otwór w posadzce zlokalizowany przy wejściu i zabezpieczony kamienną płytą. Górna kondygnacja, oświetlona trzema

\footnotetext{
Trębickiej i Stanisława Rzewuskiego. Projektantem budowli był Kazimierz Zajączkowski, absolwent petersburskiego Instytutu Inżynierów Cywilnych (ukończył go w 1880 r.) i budowniczy powiatu węgrowskiego (1881-1904), twórca bliźniaczo podobnych kościołów w Miedznie, Stoczku Węgrowskim i Grębkowie. Architekt nie doczekał ukończenia budowy. Zmarł 20 listopada 1904 r. w Winnicy, w guberni podolskiej. БАРАНОВСКИЙ 1893, s. VI; Co słychać? 1901, s. 188; Kronika. Zmarli, 1905, s. 18; ŁOZA 1954, s. 339; MAJDOWSKI 1991, s. 129; MAJDOWSKI 2011, s. 80-81.
} 
TECHNE

T E X N H

SERIA NOWA

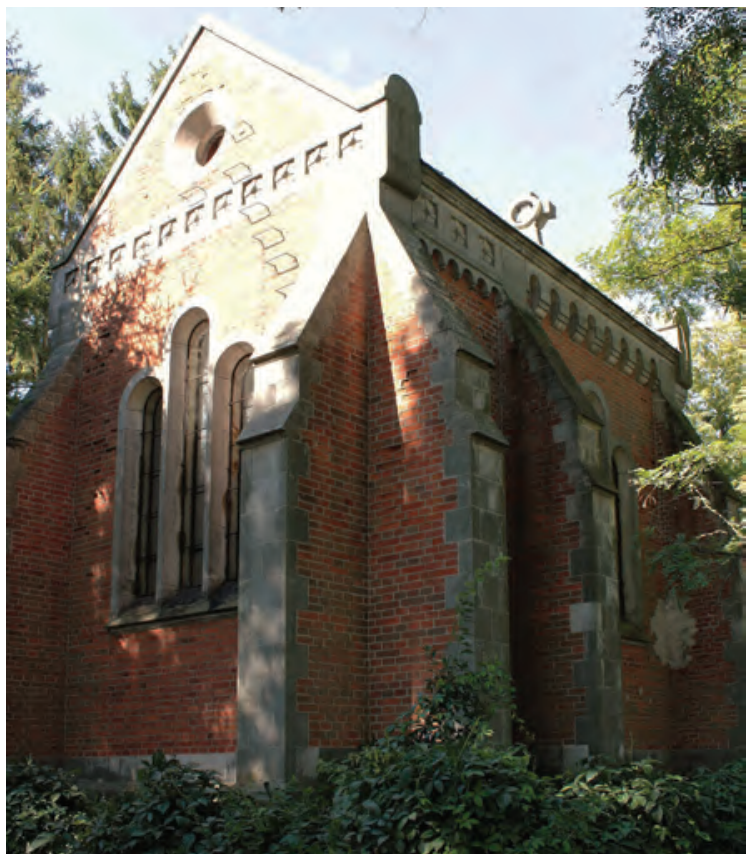

2. Kaplica grobowa Trębickich $w$ Zembrowie - elewacje tylna i boczna. Fot. M. Wiraszka, 2011

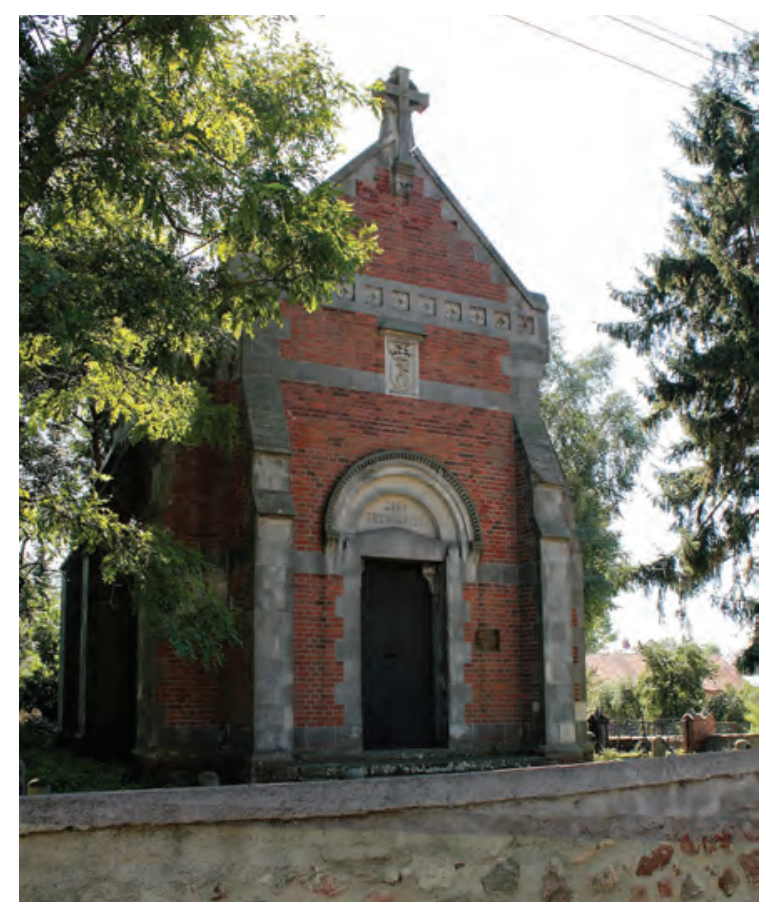

3. Fasada kaplicy Trębickich $w$ Zembrowie Fot. M. Wiraszka, 2011 


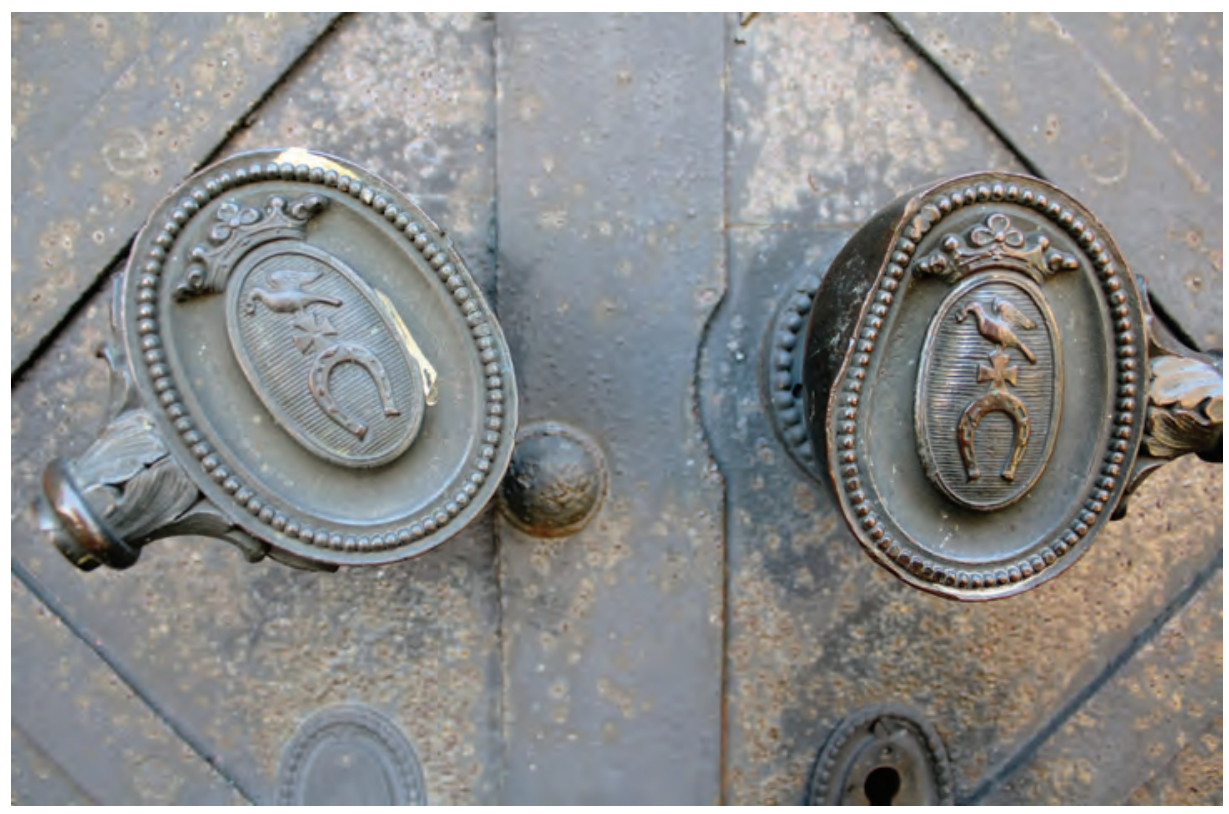

4. Herb Ślepowron umieszczony na klamkach drzwi kaplicy w Zembrowie. Fot. M. Wiraszka, 2011

potrójnymi, wysokimi i wąskimi oknami w układzie piramidalnym (wszystkie otwory zamknięte półkoliście), mieści skromny ołtarz z białego marmuru, kropielnicę ozdobioną uskrzydloną główką anielską - na ścianie po lewej stronie od wejścia - oraz umieszczone na ścianach liczne tablice epitafijne z marmuru o wyblakłej barwie czerwonobrązowej lub czarnej ze złotymi napisami ${ }^{3}$. Płyty z inskrypcjami razem $\mathrm{z}$ biało-czarną układaną $\mathrm{w}$ szachownicę posadzką przełamują monotonię wnętrza, otynkowanego na biało i oświetlonego równomiernie przez światło wpadające przez bezbarwne szyby, stanowiąc jego wyraźny i jedyny akcent kolorystyczny.

Dotychczasowa wiedza na temat kaplicy w Zembrowie, prezentowana na łamach wydawnictw przewodnikowych i odnotowana w nielicznych pracach naukowych $^{4}$, pochodziła przede wszystkim z inskrypcji znajdujących się $\mathrm{w}$ obiekcie, niepoddawanych dotąd krytycznej weryfikacji.

3 Tablice inskrypcyjne z marmuru czerwonobrązowego znajdują się pod oknami, na obu ścianach. Jest ich dwanaście, po sześć z każdej strony. Tablice z marmuru czarnego umieszczono następująco: dwie na ścianach bocznych przęsła ołtarzowego i jedną nad drzwiami wejściowymi.

4 Kaplica Trębickich po raz pierwszy wzmiankowana była przy okazji konsekracji murowanego kościoła w Zembrowie (1 X 1905). „Tygodnik Ilustrowany” informował wówczas, że z powodu dużej liczby uczestników uroczystości część z nich zmuszona była do szukania miejsca w starym kościele drewnianym i w znajdującej się obok niego kaplicy grobowej. Podstawową faktografię obiektu, jego opis oraz informacje o pochowanych tam osobach podały dopiero powojenne przewodniki. Wśród nich na szczególną uwagę zasługuje książka Mariana Pietrzaka zatytułowana Kościoły i cmentarze ziemi sokołowskiej, w której autor skrupulatnie przytacza treść inskrypcji 
Czas powstania i fundatorów budowli określa tablica erekcyjna znajdująca się nad drzwiami we wnętrzu, której treść warto przytoczyć w całości:

Kaplica ta pod wezwaniem św. Ludwika postawiona w roku 1851 przez Ludwika i Emilię Taszyckich. Z gruntu odbudowana w 1884 przez syna ich Stanisława wraz z żoną Emilią z Trębickich ku uczczeniu Chwały Bożej, oraz pamięci spoczywających tu Rodziców Jego i dzieci Kazimierza, Róży i Marii.

Na podstawie tego przekazu można wnioskować albo że na obecnym miejscu znajdowała się jedna kaplica, którą trzydzieści lat później gruntownie przebudowano, albo że były to dwie różne budowle grobowe wzniesione w odstępie ponad trzydziestoletnim jedna po drugiej. Autorzy opracowań, którym bliższa była wersja pierwsza, sądzili, że nad starą kryptą grobową z połowy XIX wieku została zbudowana w 1884 roku nowa kondygnacja ${ }^{5}$. Wydaje się to jednak mało prawdopodobne, ponieważ zarówno rozplanowanie podziemi, jak i nadziemna struktura architektoniczna są ze sobą ściśle powiązane. Obie zatem części - dolny i górny poziom - musiały powstać jednocześnie, w tym samym czasie. Kaplicę postawioną w roku 1851 zbudowali małżonkowie, Ludwik Zefiryn Trębicki (1797-1858) i Emilia Taszycka (1809-1878), którzy po ślubie w 1833 roku zamieszkali w dobrach Kurowice zakupionych na licytacji w 1828 roku przez ojca panny młodej, Franciszka Taszyckiego ${ }^{6}$. Budowę nowej kaplicy ukończył w 1884 roku ich syn Stanisław Ludwik (1838-1890) wspólnie z żoną Emilią z Trębickich (1845-1905). Ojcowie małżonków, Ludwik Zefiryn i Kazimierz Stanisław, byli rodzonymi braćmi, synami Antoniego Trębickiego (1763-1834) - dzierżawcy podwarszawskiej wsi Łomna i jego pierwszej

mieszczących się wewnątrz kaplicy. Izabella Galicka i Hanna Sygietyńska, autorki jedynej publikacji naukowej na ten temat, odnotowały jedynie fakt, że na cmentarzu grzebalnym znajduje się murowana kaplica grobowa Trębickich, i podały błędnie rok jej powstania - 1861. Zagadnienie proweniencji architektonicznej i autorstwa projektu nie były dotąd poruszane. Zob. Kronika. Uroczystość, 1905, s. 764; KZSP 1965, s. 32; PIETRZAK 2002, s. 206-214; BARBASIEWICZ 2008, s. 109; ŻABICKI 2010, s. 285.

5 Taką informację zawiera notatka zamieszczona 6 maja 2013 r. na stronie www.ciekawepodlasie.pl; por. również Załącznik nr 1 do uchwały z dn. 19 marca 2008 r. rady gm. Sabnie, dostępny na stronie www.e-bip.pl. Por. Grób Trębickich - Zembrów, www.ciekawepodlasie.pl/info/i/pl/1794/ Grob_Trebickich.html [dostęp: 8.08.2019]; Zmiana studium uwarunkowań i kierunków zagospodarowania przestrzennego gminy Sabnie, Załącznik nr 1 do uchwały z dn. 19 marca 2008 r. rady gm. Sabnie, www.e-bip.pl [dostęp: 8.08.2008].

6 Forma architektoniczna pierwszej kaplicy nie jest znana. Niewykluczone, że była ona drewniana, tak jak kaplice grobowe rodzin Łojków na cmentarzu w Zakroczymiu (1844 - niezachowana, wygląd znany z drzeworytu zamieszczonego w „Tygodniku Ilustrowanym”) czy Mycielskich w Brwinowie (XVIII/XIX w.). Zob. Kaplica rodziny Łojków, 1866, s. 196-197. 
małżonki, Marii Elżbiety Czerskiej (1773-1839)7 ${ }^{7}$ Świadectwem bliskiego pokrewieństwa obojga małżonków mogło być nieprzypadkowe, podwójne rozmieszczenie emblematu rodowego na drzwiach wejściowych.

Nowa fundacja, której celem - wspomnianym w inskrypcji erekcyjnej - było uczczenie pamięci pochowanych tu wcześniej rodziców Stanisława Trębickiego i trójki jego dzieci ${ }^{8}$, stworzyła sposobność do wzniesienia okazałego mauzoleum rodowego. Wyrazem tych aspiracji był rozbudowany program inskrypcyjny mieszczący się wewnątrz budowli, który uwzględniał nazwiska osób tutaj niepochowanych, ale będących zasłużonymi członkami rodziny Trębickich. Pod oknami ścian bocznych w sześciu prostokątnych płycinach zamkniętych od góry dwubocznie umieszczono łącznie dwanaście jednakowych tablic marmurowych z wyrytymi w zwieńczeniu herbami. Wśród nich znalazły się inskrypcje upamiętniające dziadka fundatorów, Antoniego Trębickiego (zm. 1834) - posła inflanckiego na sejmie czteroletnim (pochowany w kaplicy grobowej Trębickich w Łomnie pod Warszawą), dwóch synów Antoniego: wuja Stanisława Adama Trębickiego (1792-1830) - generała brygady wojska polskiego (pochowany na cmentarzu Powązkowskim) oraz ojca i teścia Kazimierza Stanisława Trębickiego (1798-1864) - prezesa Senatu w Królestwie Polskim (pochowany w kościele kapucynów w Warszawie), jak również dziadka Stanisława Trębickiego ze strony matki, Franciszka Taszyckiego (ok. 1771-1841) - oficera wojsk polskich pod dowództwem Kościuszki i właściciela dóbr Kurowice (pochowany w kaplicy w Zembrowie) ${ }^{9}$.

\footnotetext{
7 Ustalenia poczynione na podstawie aktów stanu cywilnego i nekrologów. Zob. APŚK 1791; AAW 1798; APW 1825; APW 1829; APW 1833; APW 1858; AAW 1864, nr 490; APS 1890; APS 1892; „Kurier Warszawski” 1905.

$8 \quad \mathrm{Z}$ trójki dzieci Stanisława Ludwika i Emilii Trębickich udało się odnaleźć na razie akt zgonu Róży Marii Pauliny Ireny Trębickiej, zmarłej w Kurowicach 7 czerwca 1881 r. w wieku 13 lat. Zob. APS 1881.

9 Informacje o zasługach członków rodziny Trębickich pochodzą z tablic inskrypcyjnych znajdujących się wewnątrz kaplicy, aktów stanu cywilnego oraz publikowanych biogramów. Tablice z inskrypcjami rozmieszczono następująco: pierwszych sześć po prawej stronie, zaczynając od przęsła ołtarzowego, zostało poświęconych: Antoniemu Trębickiemu, Stanisławowi Trębickiemu, Kazimierzowi Trębickiemu, Róży z Sikorskich Trębickiej - żonie Kazimierza (zm. 1870, lat 61 - tu pochowanej), Michałowi Trębickiemu - malarzowi, synowi Kazimierza i Róży Trębickich (zm. 1902, lat 60 - tu pochowany) oraz Franciszkowi Taszyckiemu; następnych sześć po lewej stronie, zaczynając od wejścia, zostało dedykowanych: Magdalenie z Moczulskich Targońskiej - siostrze żony Franciszka Taszyckiego, Bogumiły (zm. 1848, lat 68 - tu spoczywa), Stanisława Trębickiego - dziedzica dóbr Piekary, syna Kazimierza i Róży Trębickich (zm. 1908 - tu pochowany), Tekli z Trębickich margrabiny Spinola - córki Kazimierza i Róży Trębickich (zm. 1908 - pochowana w Lermie), Zdzisława Okęckiego - dyplomaty (zm. 1940 - tu pochowany), Zofii z hr. Skarbków Okęckiej - żony Zdzisława Okęckiego (zm. 1963 - tu spoczywa) oraz Kazimierza Trębickiego - dyplomaty i ostatniego właściciela majątku Kurowice, syna Władysława Trębickiego i Ludwiki z d. Orzeszek (zm. 1981, lat 85 - pochowany na cmentarzu Powązkowskim). Tablice dedykowane fundatorom kaplicy, Stanisławowi Ludwikowi Trębickiemu i jego żonie Emilii
} 
Tej samej idei - szlacheckiego mauzoleum rodowego - podporządkowana została architektura kaplicy grobowej odwołująca się do form średniowiecznych, kojarzonych z odległą przeszłością. Dla rodziny Trębickich, która stosunkowo niedawno, bo w latach 30. XIX wieku osiadła w powiecie sokołowskim, mogło to mieć znaczenie uwiarygodniające starożytne pochodzenie rodu. Uprawnione tym bardziej, że korzenie rodziny wywodziły się z Trębic na Podlasiu, gdzie były udokumentowane od drugiej połowy XV wieku ${ }^{10}$.

Charakteryzująca zembrowską kaplicę szlachetna prostota form o zrównoważonych proporcjach oraz wysublimowany i oszczędnie stosowany detal nie były jednak dziełem miejscowego architekta. Wysoki poziom wykonania nie szedł $\mathrm{w}$ tym przypadku w parze z oryginalnością projektu. Kaplica w Zembrowie stanowi bowiem wierną kopię budowli grobowej arystokratycznej rodziny Berghesów, zaprojektowanej i wzniesionej na cmentarzu w Rânes (rejon Normandia, departament Orne) przez architekta Victora Rupricha-Roberta $(1820-1887)^{11}$.

Nieznany jest dokładny rok powstania projektu francuskiej kaplicy noszącej wezwanie św. Piotra. Wiadomo jednak, że musiało to nastąpić po śmierci Pierre’a de Berghesa, który w wyniku odniesionych ran w bitwie pod Sedanem (1 IX 1870) zmarł w Brukseli 23 października 1870 roku, mając 24 lata. Rodzina zamówiła plany budowli u Rupricha-Roberta, który był wówczas architektem diecezjalnym departamentu Orne, a wcześniej restaurował będący ich własnością Châteaux de Rânes (ok. 1850?). Prace przy kaplicy musiały zostać ukończone w 1873 roku, ponieważ w połowie roku, dokładnie 24 lipca, przeniesiono tam trumny Pierre’a de Berghesa oraz kilku innych członków rodziny. Na tej podstawie monografista architekta Xavier Gille przyjął za najbardziej wiarygodny termin budowy kaplicy lata $1872-1873^{12}$.

Dokumentacja architektoniczna kaplicy w Zembrowie została najpewniej przygotowana na miejscu przez budowniczego powiatowego lub architekta pochodzącego z Warszawy w oparciu o zamieszczone we francuskim czasopiśmie branżowym „Revue générale de l’architecture et des travaux publics” plany kaplicy Berghesów, które opublikowano w $1876 \mathrm{roku}^{13}$. Zmiany wprowadzone do polskiej wersji projektu

\footnotetext{
z Trębickich, 1 voto Trębickiej, 2 voto Starzeńskiej, zostały umieszczone przy ołtarzu na bocznych ścianach. Zob. APŚK 1792; APW, Akt 1830, nr 249; APW 1830, nr 2105; Kazimierz Trębicki 2013.

10 Minakowski 2013, s. 236, 249.

11 Victor Ruprich-Robert - architekt i konserwator zabytków, urodzony w Paryżu 18 lutego 1820 r., zmarły 7 maja 1887 r. w Cannes, był absolwentem Ėcole des Beaux-Arts. Oprócz kaplicy w Rânes jego dziełem była budowla grobowa rodziny Taillepied de Bondy na cmentarzu Père Lachaise w Paryżu (1848). Zob. Ruprich-RoBerT 1849, s. 164-166, pl. 33-36; Les architectes 1907, s. 396; GILLE 2013, s. 9-18, 52.

12 Gille 2013, s. 45, 62.

13 RUPrich-Robert 1876, szp. 50-52, pl. 17-20. W artykule nie zamieszczono planszy nr 20, na której umieszczono projekty wyposażenia drewnianego kaplicy: klęcznika i krzesła.
} 


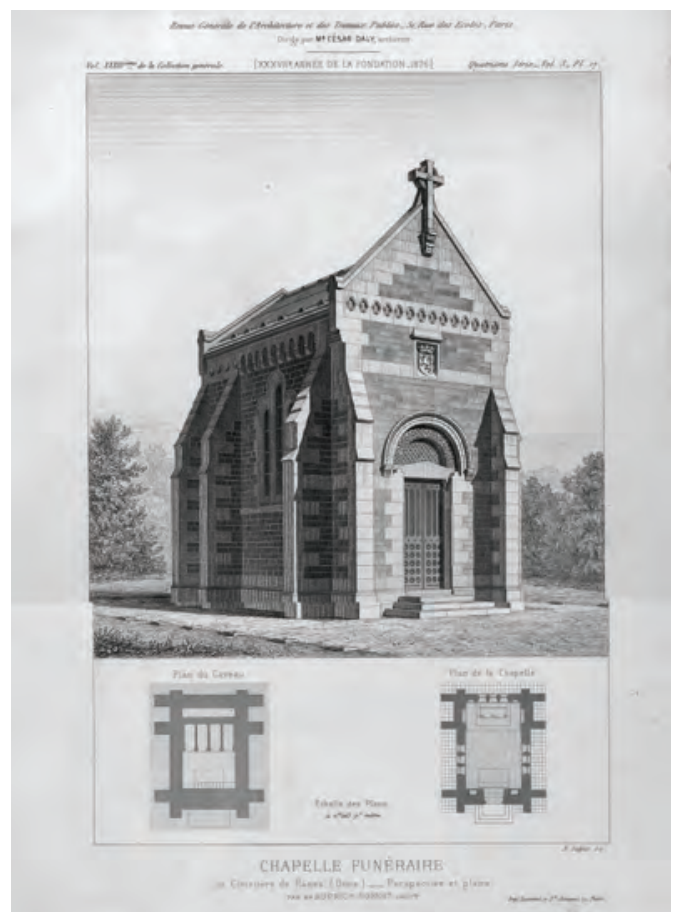

5. Projekt kaplicy w Rânes autorstwa V. Rupricha-Roberta. Widok perspektywiczny i plan obu kondygnacji Repr. z: «Revue générale de l'architecture et des travaux publics» vol. XXXIII, 1876, n² 2, pl. 17

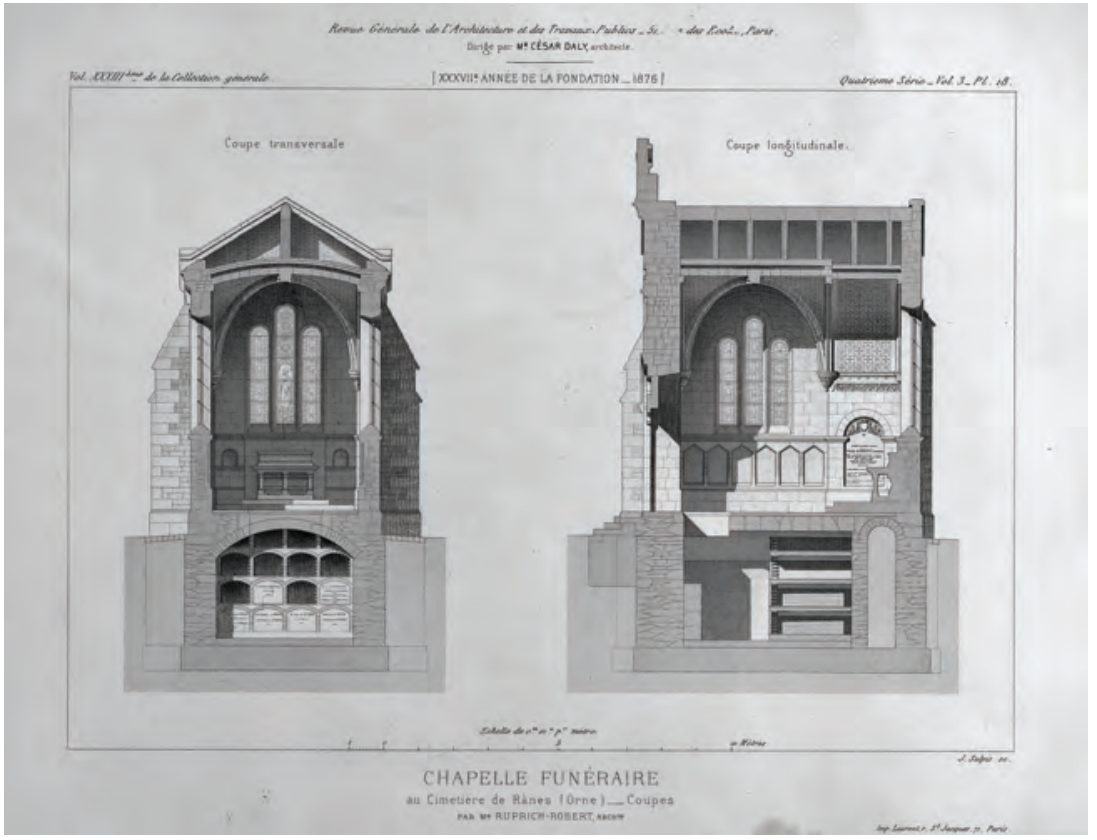

6. Projekt kaplicy w Rânes autorstwa V. Rupricha-Roberta. Przekrój podłużny i poprzeczny Repr. z: «Revue générale de l'architecture et des travaux publics» vol. XXXIII, 1876, n² 2, pl. 18 


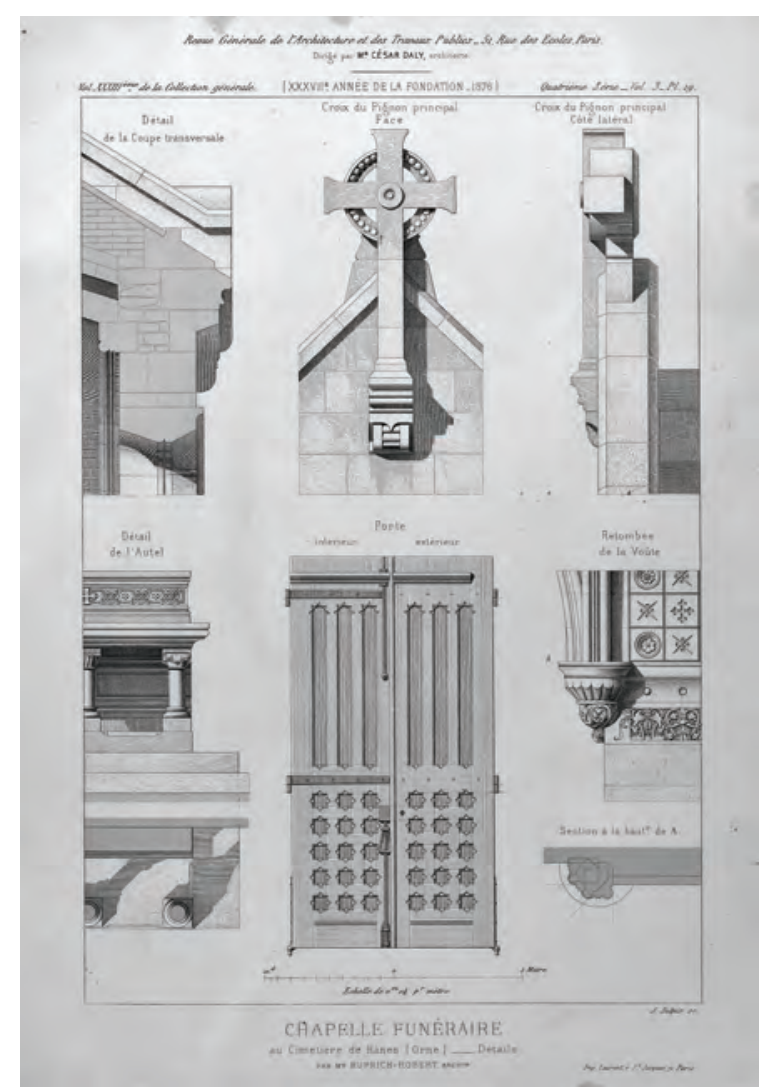

7. Projekt kaplicy w Rânes autorstwa V. Rupricha-Roberta. Elementy wystroju i wyposażenia Repr. z: «Revue générale de l'architecture et des travaux publics» vol. XXXIII, 1876, n² 2, pl. 19

były niewielkie. Ograniczały się do pominięcia części elementów lub zastąpienia ich innymi formami, i dotyczyły głównie wnętrza kaplicy. Brakuje m.in. ornamentów zdobiących powierzchnię tympanonu i wewnętrzną archiwoltę portalu, a we wnętrzu kaplicy pokrywających podniebienie kolebki, tworzących fryz na bocznych ścianach przęsła ołtarzowego oraz dekorujących wsporniki sklepienia krzyżowo-żebrowego $\mathrm{w}$ nawie. Zrezygnowano ponadto z powtórzenia dekoracji reliefowej zdobiącej drzwi wejściowe. Celowo lub z powodu niezrozumienia formy nie odtworzono wianków w okrągłych wnękach prostokątnego fryzu w szycie fasady i na elewacjach przęsła ołtarzowego, wprowadzając w tym miejscu zgeometryzowany detal ornamentacyjny, nieprzypominający oryginału. Za to niemal dosłownie odtworzono formę ołtarza ustawionego przy ścianie na wprost wejścia. Mensę, na której umieszczono niską prostokątną nastawę dekorowaną wypukłym roślino-plecionkowym ornamentem, podpierają odsunięte od ściany trzy kolumienki. Jej uzupełnienie stanowi tabernakulum wkomponowane $\mathrm{w}$ środek nastawy, które jest elementem dodanym, niewystępującym we francuskim pierwowzorze. Zgodnie z oryginalnym 
projektem powtórzono jeszcze rozmieszczenie prostokątnych płycin zamkniętych dwubocznie, stosując występujące w pierwowzorze sfazowanie krawędzi oraz wprowadzając profilowany gzyms obiegający ściany poniżej parapetów okiennych.

Zespół detali architektonicznych użytych do ozdoby francuskiej kaplicy, jak kapitele piszczałkowe, dwuboczne łuki czy ornamentacyjne plecionki, należał do repertuaru form romańskich, typowych dla Normandii. Ruprich-Robert znał je bardzo dobrze, ponieważ w swojej praktyce zawodowej jako restaurator często pracował przy odnawianiu średniowiecznych budowli zabytkowych w tym regionie, w tym kościołów Ste-Trinité (1854-1868) i St-Etienne w Caen (1867-1883) ${ }^{14}$. Zebrany w trakcie prowadzonych prac restauracyjnych i odbytych podróży materiał został przez niego opublikowany w $1885 \mathrm{r}$. w formie dwutomowej monografii zatytułowanej L'Architecture Normande aux XI et XII sièctes en Normandie et en Angleterre, do której dołączył 48 plansz prezentujących najciekawsze obiekty z obszaru północnej Francji ${ }^{15}$. Przedstawione na planszach detale stanowią świadectwo dogłębnych badań architektonicznych. Pominięcie w projekcie kaplicy zembrowskiej części elementów dekoracyjnych mogło mieć dwojaką przyczynę. Na polskiej prowincji formy te mogły wydawać się zbyt obce i niezrozumiałe, ale też koszt całkowity wzniesienia obiektu z dodatkowymi ozdobami mógł być zbyt duży ${ }^{16}$. Obniżeniu wydatków miała zapewne służyć również rezygnacja z wykorzystania granitu - czerwono-żółtego i szarego przy konstrukcji ścian zewnętrznych oraz wapienia do okładziny wnętrza, i zastąpienie ich tańszą cegłą oraz piaskowcem, które to materiały dzięki swojemu naturalnemu kolorytowi naśladowały pierwotnie zaplanowaną przez francuskiego architekta kolorystykę elewacji. Z tych samych powodów oryginalny łupek z ołowianymi wywietrznikami został zastąpiony blachą cynkową ${ }^{17}$.

Kaplica Trębickich w Zembrowie jest jedną z wielu polskich budowli grobowych inspirowanych francuskimi realizacjami. Dotychczasowe badania prowadzone nad tym zagadnieniem wskazują ${ }^{18}$, że statystycznie najwięcej takich obiektów powstało na cmentarzach katolickich w Warszawie (33) i na terenie Królestwa Polskiego (9) ${ }^{19}$.

\footnotetext{
14 Gille 2013, s. 23-24, 26.

15 Ibidem, s. 81-82.

16 Kwota poniesionych wydatków przy realizacji francuskiej kaplicy wyniosła blisko 35000 franków: RUPRICH-ROBERT 1876, szp. 52.

17 Ibidem, szp. 51-52.

18 Pierwszą pracą, w której przeanalizowano źródła inspiracji form architektonicznych w odniesieniu do budowli grobowych znajdujących się na cmentarzu, była publikacja Jana Dominikowskiego z 2004 r. poświęcona Cmentarzowi Staremu przy ul. Ogrodowej w Łodzi. Wcześniej były to monograficzne ujęcia wybranych obiektów, np. rodziny Braeunigów na warszawskim cmentarzu luterańskim czy Karola Scheiblera oraz rodziny Heinzlów na Cmentarzu Starym w Łodzi. Zob. Dominikowski 2004, s. 219-243; RADŹWICKA-MilczewsKa 1994; STEFAńSKi 1996; STEFAŃSKi 2003.

19 Zob. zestawienie obiektów na końcu artykułu. Informacje na ich temat znajdują się w publikacji: WiRASZKA 2019, s. 225-324 (tam dalsza literatura).
} 
Do najstarszych należą mauzolea Petyskusów na warszawskim cmentarzu ewangelicko-augsburskim (1836-1838) i na cmentarzu przykościelnym w Starej Rawie niedaleko Skierniewic - rodziny Prandotów Trzcińskich (ok. 1840). Oba powstały pod wpływem tego samego wydawnictwa Louisa Marie Normanda z roku 1832 i wzorowane były na empirowym mauzoleum rodziny Frochot na cmentarzu Père Lachaise (proj. Ė.H. Godde, 1828-1829). Przy czym w projekcie warszawskim formy te połączono z elementami dekoracyjnymi pochodzącymi ze steli z inicjałami „HR”, przeznaczonej na cmentarz Montmartre w Paryżu (przed 1832) ${ }^{20}$. Obecność tych wzorów w Polsce była konsekwencją ukazania się w Paryżu w latach 30. kilku bogato ilustrowanych wydawnictw poświęconych tamtejszym cmentarzom i pomnikom grobowym. Oprócz już wymienionej publikacji Normanda na szczególną uwagę zasługują prace Ferdinanda Quaglii (1832) i Josepha Marty'ego (1839) ${ }^{21}$. Trzy wydane w Paryżu albumy dostarczyły twórcom warszawskim i prowincjonalnym gotowych wzorów. Ich wszechstronne wykorzystanie dokumentuje znaczna liczba pomników nagrobnych postawionych na stołecznych nekropoliach w latach $1840-1860^{22}$.

Początkowo niewielkie zainteresowanie budowlami grobowymi współcześnie realizowanymi na cmentarzach francuskich ulega zmianie w połowie lat 70. XIX wieku. Na cmentarzu Powązkowskim powstają wówczas kaplice rodzin Okóniów (przed 1876), Lachnickich (1878) i Ignacego Znamierowskiego (1882), a na cmentarzu prawosławnym na Woli wznosi się mauzoleum Nikifora Wasiliewa (1876) ${ }^{23}$. Poza Warszawą budują się kaplice rodzin Nowickich w Juchnowcu Kościelnym $(1880-1881)^{24}$ i Karola Scheiblera na Cmentarzu Starym w Łodzi (1885-1888)25. $\mathrm{Z}$ tego samego okresu pochodzi również kaplica grobowa Trębickich w Zembrowie (1884). Wspólnym mianownikiem dla wymienionych budowli jest stosunkowo krótki czas, jaki upływał pomiędzy powstaniem projektu we Francji a jego realizacją na ziemiach polskich, wynoszący średnio osiem lat. Dystans ten ulegnie zmianie dopiero w latach 90. XIX wieku. Realizowane wtedy budowle - wśród których znajduje się pięć kaplic na warszawskich Starych Powązkach, własność rodzin Leopolda Kronenberga (1892-1893), Stanisława Wołowskiego (1894), Wiktorskich i Morawskich (1895), Hipolita Cieszkowskigo (1895), Ludwika Didiera (ok. 1903) oraz Augusta i Katarzyny Jüttnerów na cmentarzu katolickim w Piotrkowie Trybunalskim (1897) - będzie już od pierwowzoru dzieliła różnica około 25 lat $^{26}$.

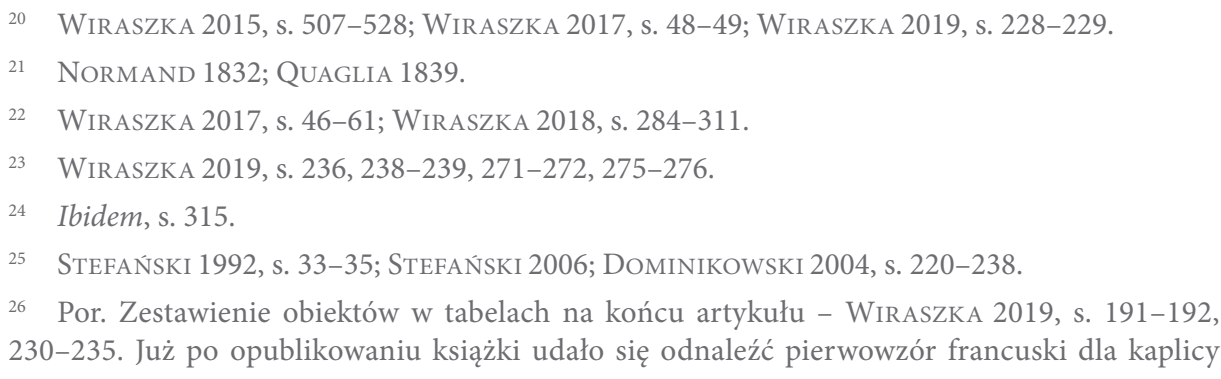


Na przyspieszenie procesu rozpowszechniania się na cmentarzach Warszawy i Królestwa Polskiego francuskich form architektonicznych miały wpływ trzy czynniki. Pierwszy wiązał się z rozwojem sieci kolejowej, która w końcu XIX wieku skracała drogę z Warszawy do Paryża do 43 godzin, podczas gdy na początku stulecia podróż taka trwała tydzień ${ }^{27}$. Drugi wynikał z fascynacji elit polskich kulturą francuską. Trzeci miał swoje źródło w wydawnictwach albumowych i czasopismach ilustrowanych, które były coraz liczniejsze i bardziej dostępne, dzięki czemu architektom ułatwiały pracę, a zleceniodawcom - skonkretyzowanie oczekiwań. Do najczęściej prenumerowanych należały czasopisma „Croquis d’Architecture”, „Moniteur des Architectes” i „Revue générale de l'architecture et des travaux publics”. Wśród albumów w drugiej połowie XIX wieku największą popularnością cieszyła się publikacja Cèsara Daly'ego Architecture Funéraire Contemporaine. Spécimens de Tombeaux, Chapelles Funéraires, Mausolées, Sarcophages, Stèles, Pierres Tombales, Croix, etc. Choisis principalement dans les Cimetières de Paris, wydana w Paryżu w 1871 roku $^{28}$.

Poza granicami Królestwa Polskiego wpływy francuskie wydają się być słabsze. Pojedyncze przykłady występują na terenie ziem pruskich, w Chełmży - kaplica Zawiszów Czarnych na cmentarzu parafialnym (1879) ${ }^{29}$ i w Leśnej koło Lubania - na terenie parku kaplica Samsona Wollera $(1882-1883)^{30}$. Z kolei w granicach zaboru austriackiego powstała na cmentarzu Łyczakowskim we Lwowie kaplica rodziny Gnoińskich (4 ćw. XIX wieku).

Ostatnia z budowli wzmiankowana w pracach Stanisława S. Niciei poświęconych nekropoli Łyczakowskiej ${ }^{31}$ nie była dotychczas rozpatrywana pod kątem pochodzenia formy architektonicznej. Ponieważ w niedalekiej przyszłości planowany jest osobny artykuł poświęcony tej kaplicy, mój komentarz ograniczę do wskazania pierwowzoru. Oryginalny projekt, powtórzony niemal bez zmian we lwowskiej kaplicy, jest dziełem francuskiego architekta Frédérica Jeana Schmidta (ur. 1862) i został zrealizowany w drugiej połowie XIX wieku w Paryżu na cmentarzu Pére Lachaise dla rodziny Clémançon. Skopiowanie projektu umożliwiła publikacja we francuskim periodyku, reprodukowanym na początku XX wieku przez Gawriła W. Baranowskiego w Encyklopedii architektury drugiej połowy XIX w. ${ }^{32}$

\footnotetext{
Ludwika Didiera, zamieszczony we wzorniku Daly'ego z 1871 r. Autorem projektu przeznaczonego do realizacji na cmentarzu Montmartre w Paryżu był architekt Dainville. Architecture Funéraire..., 1871, Section A, pl. 25-26.

27 BRzostek 2015, s. 80.

28 Architecture Funéraire..., 1871.

29 WIRASZKA 2019, s. 232.

30 GrochowsKa/STEFAŃSKi 2015, s. 31-40.

31 NiCIEJA 1998, s. 259-260, il. 252; NiCIEJA 2011, s. 259.

32 БАРАНОВСКИЙ 1902, s. 436.
} 
TECHNE

T E X N H

SERIA NOWA

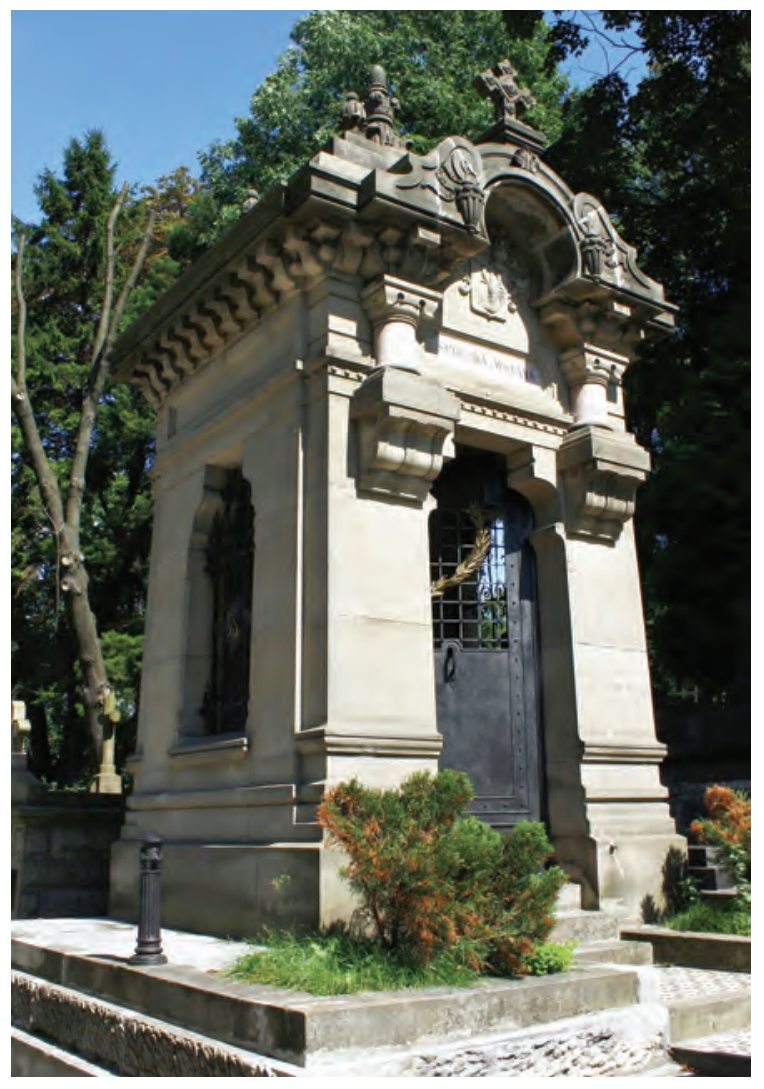

8. Kaplica Gnoińskich na cmentarzu Łyczakowskim we Lwowie Fot. B. Gutowski, 2010

Na podstawie dotychczas zinwentaryzowanych obiektów możemy wskazać dwa podstawowe źródła inspiracji form francuskich, z których korzystali architekci i zleceniodawcy przy wznoszeniu budowli grobowych na ziemiach polskich. Najliczniejszą grupę stanowią kaplice powstałe w oparciu o współcześnie tworzone przez francuskich architektów projekty, które docierały na prowincję dzięki różnorodnym publikacjom. Są to zwykle albo kopie oryginalnych projektów, albo budowle o charakterze kompilacyjnym. Drugą grupę, mniej liczną, tworzą realizacje odwołujące się do francuskiej architektury zabytkowej, np.: Saint Chapelle w Paryżu (kaplica Karola Scheiblera w Łodzi) ${ }^{33}$, kaplica królewska w Wersalu (kaplica Zamoyskich w Kozłówce) ${ }^{34}$ czy kaplica Chapelle Expiatoire w Paryżu (kaplica Samsona Wollera w Leśnej k. Lubania) $)^{35}$.

\footnotetext{
33 Dominikowski 2004, s. 235-236; STEFAŃSKi 2006, s. 63-72.

34 JABŁOŃSKA 2003, s. 29-37.

35 GrochowsKa/STEFAŃSKi 2015, s. 35.
} 


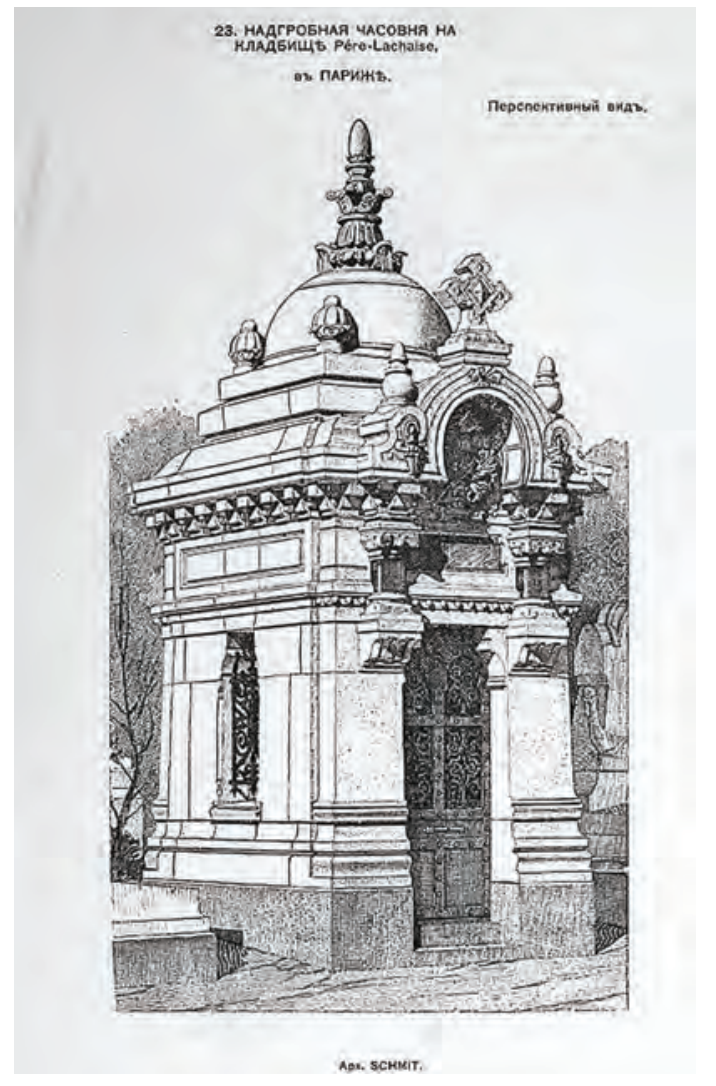

9. Projekt kaplicy rodziny Clémançon na cmentarzu Père Lachaise w Paryżu autorstwa F. J. Schmidta Repr. z: Г.В. Барановский, Архитектурная энциклопедия..., s. 436

Wszystkie budowle grobowe, niezależnie od tego, czy były stawiane w obrębie parkowej rezydencji, czy też na cmentarzu, wyróżniały się swoimi rozmiarami. $\mathrm{Na}$ dużych nekropoliach „konkurowały” dodatkowo ze sobą formą oraz materiałem. $\mathrm{Na}$ wiejskich cmentarzykach „rywalizowały” jedynie z kościołem parafialnym. Niektóre, tak jak kaplica Trębickich w Zembrowie, upodabniały się wyglądem do małego kościółka. 


\section{Aneks}

FRANCUSKIE INSPIRACJE W ARCHITEKTURZE BUDOWLI GROBOWYCH NA CMENTARZACH WARSZAWY

\begin{tabular}{|c|c|c|c|c|}
\hline Lp. & Nazwa obiektu & Cmentarz & Rok & Architekt \\
\hline 1. & m. PETYSKUSÓW & E-A & $1836-1838$ & - \\
\hline 2. & k. OKÓNIÓW & S-P & przed 1876 & - \\
\hline 3. & m. Nikifora WASILIEWA & $\mathrm{P}$ & 1876 & - \\
\hline 4. & k. LACHNICKICH & S-P & 1878 & W. Kosmowski \\
\hline 5. & k. Ignacego ZNAMIEROWSKIEGO & S-P & 1882 & - \\
\hline 6. & k. Mieczysława KISIELNICKIEGO & S-P & $1882-1889$ & - \\
\hline \multirow[t]{10}{*}{7.} & - k. KACZOROWSKICH & S-P & $1884-1885$ & - \\
\hline & - k. S. i H. URUSKICH & S-P & 1891 & - \\
\hline & - k. A. z OLENDZKICH & S-P & 1899 & - \\
\hline & MANDELSZTAM & & & \\
\hline & - k. L. i K. TOEPLITZÓW & S-P & 1903 & - \\
\hline & - k. J. i M. Rakowskich & S-P & $1909-1910$ & - \\
\hline & - k. PILECKICH & S-P & $1912-1914$ & - \\
\hline & - k. HEINÓW & S-P & 1913-1914 & - \\
\hline & - k. JAŹWIŃSKICH & S-P & $1913-1914$ & - \\
\hline & - m. KOZŁOWSKICH & S-P & przed 1927 & - \\
\hline
\end{tabular}




\begin{tabular}{|c|c|c|c|}
\hline Nazwa pierwowzoru & Cmentarz & Rok & Architekt \\
\hline PARYŻ - m. rodziny Frochot & Père Lachaise & $1828-1829$ & E.H. Godde \\
\hline i stela z inicjałami „HR” & Montmartre & przed 1832 & - \\
\hline $\begin{array}{l}\text { PARYŻ - m. rodziny Hertford- } \\
\text {-Wallace }\end{array}$ & Père Lachaise & przed 1871 & É. Gilbert \\
\hline PARYŻ - m. Maximiliena Foya & Père Lachaise & 1831 & L. Vaudoyer \\
\hline DIJON - k. rodziny N.N. & cmentarz kat. & 1871 & P. Degré \\
\hline $\begin{array}{l}\text { MONTPELLIER - kaplica } \\
\text { rodziny N.N. }\end{array}$ & $\begin{array}{l}\text { Cimetière } \\
\text { Saint-Lazare }\end{array}$ & 1868 & A. Goutés \\
\hline $\begin{array}{l}\text { PARYŻ - k. rodziny Thirion } \\
\text { PARYŻ - k. rodziny Maillard } \\
\text { PARYŻ - k. rodziny Houppin- } \\
\text {-Mariage }\end{array}$ & Père Lachaise & $\begin{array}{l}\text { przed } 1852 \\
\text { przed } 1852 \\
\text { przed } 1852\end{array}$ & $\begin{array}{l}- \\
- \\
-\end{array}$ \\
\hline \multicolumn{4}{|c|}{$\begin{array}{l}\text { Typ niedużej, liczącej zaledwie } 1 \text { x } 2 \text { m powierzchni, dwupoziomowej kaplicy z kryptą } \\
\text { dostępną przez otwór w posadzce, charakterystycznej dla cmentarzy paryskich - szcze- } \\
\text { gólnie Père Lachaise. }\end{array}$} \\
\hline
\end{tabular}


FRANCUSKIE INSPIRACJE W ARCHITEKTURZE BUDOWLI GROBOWYCH NA CMENTARZACH WARSZAWY (cd.)

\begin{tabular}{|c|c|c|c|c|}
\hline Lp. & Nazwa obiektu & Cmentarz & Rok & Architekt \\
\hline \multirow[t]{9}{*}{8.} & - k. Edwarda REYCHA & S-P & 1887 & - \\
\hline & - k. Michała SOŁTYKIEWICZA & S-P & $1888-1890$ & - \\
\hline & - k. Józefa PRASAŁOWSKIEGO & S-P & $1890-1899$ & - \\
\hline & - k. Wilhelma MÜCKA & S-P & 1995 & - \\
\hline & - k. Tytusa KOWALSKIEGO & S-P & 1897 & - \\
\hline & - k. Edwarda DOBOSIEWICZA & S-P & 1898 & - \\
\hline & - k. RZESZOTARSKICH & S-P & $1897-1900$ & - \\
\hline & - k. SAFARZYŃSKICH & S-P & $1897-1911$ & - \\
\hline & $\begin{array}{l}\text { - k. SAWICKICH i LUBICZ- } \\
\text {-ŻÓŁKIEWSKICH }\end{array}$ & S-P & ok. 1912 & - \\
\hline 9. & k. Richarda KIMENSA & $\mathrm{E}-\mathrm{R}$ & $1885-1886$ & - \\
\hline 10. & - k. Aleksandra KAMOCKIEGO & S-P & 1888 & - \\
\hline & - k. „Pamięci Drogiego Wacława” & S-P & ok. $1888-1889$ & - \\
\hline & $\begin{array}{l}\text { - k. Aleksandra KWAŚNIEW- } \\
\text { SKIEGO }\end{array}$ & S-P & ok. 1920 & - \\
\hline 11. & k. Leopolda KRONENBERGA & S-P & $1892-1893$ & A. Goebel \\
\hline 12. & k. Stanisława WOŁOWSKIEGO & S-P & 1894 & - \\
\hline 13. & $\begin{array}{l}\text { k. WIKTORSKICH I MORAW- } \\
\text { SKICH }\end{array}$ & S-P & 1895 & - \\
\hline 14. & k. Hipolita CIESZKOWSKIEGO & S-P & 1895 & - \\
\hline 15. & k. Ludwika DIDIERA & S-P & ok. 1903 & - \\
\hline
\end{tabular}




\begin{tabular}{|c|c|c|c|}
\hline Nazwa pierwowzoru & Cmentarz & Rok & Architekt \\
\hline $\begin{array}{l}\text { SAINT JEAN D'ANGELY } \\
\text { - k. rodziny Bac } \\
\text { LE MANS - k. rodziny Fouche }\end{array}$ & $\begin{array}{l}\text { cmentarz kat. } \\
\text { cmentarz kat. }\end{array}$ & $\begin{array}{l}2 \text { poł. XIX w. } \\
2 \text { poł. XIX w. }\end{array}$ & _ \\
\hline $\begin{array}{l}\text { PARYŻ - k. rodziny Taillepied } \\
\text { de Bondy }\end{array}$ & Père Lachaise & 1847 & $\begin{array}{l}\text { V. Ruprich- } \\
\text {-Robert }\end{array}$ \\
\hline PARYŻ - k. Bourdois de Motte & Père Lachaise & ok. 1836 & - \\
\hline PARYŻ - kaplica cmentarna & Père Lachaise & 1820 & È.H. Godde \\
\hline DRAVEIL - k. rodziny Dida & cmentarz kat. & 1878 & F. Jourdaina \\
\hline PARYŻ - k. rodziny Grimaldi & Montmartre & przed 1871 & P. Manguin \\
\hline PARYŻ - k. rodziny de Boutet & Père Lachaise & $1854-1855$ & L. Salleron \\
\hline PARYŻ - k. «Tombeaux de Famille» & Père Lachaise & przed 1871 & E. Morin \\
\hline $\begin{array}{l}\text { PARYŻ - k. rodzin Lapie } \\
\text { i Porquerelle }\end{array}$ & Montmartre & przed 1871 & ? Dainville \\
\hline
\end{tabular}


FRANCUSKIE INSPIRACJE W ARCHITEKTURZE BUDOWLI GROBOWYCH KRÓLESTWA POLSKIEGO

\begin{tabular}{|c|c|c|c|c|}
\hline Lp. & Nazwa obiektu & Cmentarz & Rok & Architekt \\
\hline 1. & $\begin{array}{l}\text { STARA RAWA - m. Prandotów } \\
\text { Trzcińskich }\end{array}$ & $\begin{array}{l}\text { cmentarz } \\
\text { przykościelny }\end{array}$ & ok. 1840 & - \\
\hline 2. & $\begin{array}{l}\text { JUCHNOWIEC KOŚCIELNY } \\
\text { k. Białegostoku - kaplica Nowickich }\end{array}$ & cmentarz par. & $1880-1881$ & - \\
\hline 3. & ZEMBRÓW - k. Trębickich & $\begin{array}{c}\text { teren } \mathrm{d} . \mathrm{cm} . \\
\text { przykościelnego }\end{array}$ & 1884 & - \\
\hline 4. & ŁÓDŹ - k. Karola Scheiblera & $\begin{array}{l}\text { cmentarz } \\
\text { ewangelicki }\end{array}$ & $1885-1888$ & $\begin{array}{l}\text { E. Lilpop } \\
\text { i J.P. Dziekoński }\end{array}$ \\
\hline 5. & $\begin{array}{l}\text { ŻYRARDÓW - k. Mikołaja } \\
\text { Wątróbskiego }\end{array}$ & cmentarz kat. & ok. 1894 & - \\
\hline 6. & $\begin{array}{l}\text { PIOTRKÓW TRYBUNALSKI } \\
\text { - k. Augusta i Katarzyny Jüttnerów }\end{array}$ & cmentarz kat. & 1897 & - \\
\hline 7. & KALISZ - k. Prusinowskich & cmentarz kat. & pocz. XX w. & - \\
\hline 8. & KOZŁÓWKA - k. Zamoyskich & obok pałacu & 1903-1909 & J.F. Heurich mł. \\
\hline 9. & $\begin{array}{l}\text { WRÓBLEW k. Sieradza } \\
\text { - k. Feliksa Radońskiego }\end{array}$ & cmentarz par. & przed 1926 & - \\
\hline
\end{tabular}

FRANCUSKIE INSPIRACJE W ARCHITEKTURZE BUDOWLI GROBOWYCH POZA KRÓLESTWEM POLSKIM

\begin{tabular}{|c|l|c|c|c|}
\hline Lp. & \multicolumn{1}{|c|}{ Nazwa obiektu } & Cmentarz & Rok & Architekt \\
\hline 1. & CHEŁMŻA - k. Zawiszów Czarnych & cmentarz par. & 1879 & - \\
\hline 2. & $\begin{array}{l}\text { LEŚNA k. Lubania - k. Samsona } \\
\text { Wollera }\end{array}$ & park dworski & $1882-1883$ & C. Lüdecki \\
\hline 3. & LWÓW - k. Gnoińskich & $\begin{array}{c}\text { cmentarz } \\
\text { Łyczakowski }\end{array}$ & 4 ćw. XIX w. & - \\
\hline
\end{tabular}




\begin{tabular}{|c|c|c|c|}
\hline Nazwa pierwowzoru & Cmentarz & Rok & Architekt \\
\hline PARYŻ - m. rodziny Frochot & Père Lachaise & $1828-1829$ & È.H. Godde \\
\hline DIJON - k. rodziny N.N. & cmentarz kat. & 1871 & P. Degré \\
\hline RÂNES - k. rodziny de Berghes & $\begin{array}{l}\text { Cimetière } \\
\text { Saint-Pierre }\end{array}$ & $1872-1873$ & $\begin{array}{l}\text { V. Ruprich- } \\
\text {-Robert }\end{array}$ \\
\hline PARYŻ - kaplica Saint Chapelle & $\begin{array}{l}\text { kaplica } \\
\text { pałacowa }\end{array}$ & $1240-1248$ & P. de Montreuil \\
\hline PARYŻ - k. Bourdois de Motte & Père Lachaise & ok. 1836 & - \\
\hline PARYŻ - kaplica cmentarna & Père Lachaise & 1820 & È.H. Godde \\
\hline $\begin{array}{l}\text { BORDEAUX - k. rodziny } \\
\text { de Carayon La Tour }\end{array}$ & $\begin{array}{c}\text { Cimetière } \\
\text { du Chartreuse }\end{array}$ & przed 1871 & H. Duphot \\
\hline $\begin{array}{l}\text { SAINT JEAN D'ANGELY } \\
-\mathrm{k} \text {. rodziny Bac }\end{array}$ & cmentarz kat. & 2 poł. XIX w. & - \\
\hline LE MANS - k. rodziny Fouche & cmentarz kat. & 2 poł. XIX w. & - \\
\hline WERSAL - kaplica królewska & - & $1698-1710$ & $\begin{array}{l}\text { J. Hardouin- } \\
\text {-Mansart }\end{array}$ \\
\hline $\begin{array}{l}\text { SAINT JEAN D'ANGELY } \\
\text { - k. rodziny Bac }\end{array}$ & cmentarz kat. & 2 poł. XIX w. & - \\
\hline LE MANS - k. rodziny Fouche & cmentarz kat. & 2 poł. XIX w. & - \\
\hline
\end{tabular}

\begin{tabular}{|c|c|c|c|}
\hline Nazwa pierwowzoru & Cmentarz & Rok & Architekt \\
\hline PARYŻ - k. rodziny de Boutet & Père Lachaise & $1854-1855$ & L. Salleron \\
\hline PARYŻ - Chapelle Expiatoire & - & $1816-1826$ & P.F.L. Fontaine \\
\hline PARYŻ - k. rodziny Clémançon & Père Lachaise & 2 poł. XIX w. & $\begin{array}{l}\text { F.J. Schmidt } \\
\text { / Schmit (?) }\end{array}$ \\
\hline
\end{tabular}




\section{Bibliografia}

\section{Źródła archiwalne}

AAW 1798 - Archiwum Archidiecezjalne Warszawskie, Akt urodzenia Ludwika Zefiryna Trębickiego, par. św. Jana Chrzciciela w Warszawie, 1798, k. 447 generosi.

AAW 1864 - Archiwum Archidiecezjalne Warszawskie, Akt zgonu Kazimierza Stanisława Trębickiego, par. św. Jana Chrzciciela w Warszawie, 1864, nr 490 (z dn. 31 października 1864).

APS 1881 - Archiwum Państwowe w Siedlcach, Akt zgonu Róży Marii Trębickiej, par. w Zembrowie, 1881, nr 30 (z dn. 10 czerwca 1881).

APS 1890 - Archiwum Państwowe w Siedlcach, Akt zgonu Stanisława Ludwika Trębickiego, Kurowice, 1890, nr 18 (z dn. 5 maja 1890).

APS 1892 - Archiwum Państwowe w Siedlcach, Akt małżeństwa Waleriana Adama hr. Starzeńskiego i Emilii $z$ Trębickich, 1 voto Trębickiej, par. w Zembrowie, 1892, nr 16 (z dn. 15 września 1892).

APŚK 1791 - Archiwum Parafii św. Krzyża w Warszawie, Akt małżeństwa Antoniego Trębickiego i Marianny Elżbiety Czerskiej, par. św. Krzyża w Warszawie, 1791, k. 86 (z dn. 17 lipca 1791).

APŚK 1792 - Archiwum Parafii św. Krzyża w Warszawie, Akt urodzenia Stanisława Adama Trębickiego, par. św. Krzyża w Warszawie, 1792, k. 96R (z dn. 6 maja 1792).

APW 1825 - Archiwum Państwowe m. st. Warszawy, Akt małżeństwa Ludwika Trębickiego i Franciszki Torri, Warszawa ASC Cyrkuł VIII (Praga), 1825, nr 40 (z dn. 6 lipca 1825).

APW 1829 - Archiwum Państwowe m. st. Warszawy, Akt małżeństwa Kazimierza Stanisława Trębickiego i Róży Tekli Sikorskiej, par. św. Krzyża w Warszawie, 1829, nr 12 (z dn. 24 stycznia 1829).

APW 1830 - Archiwum Państwowe m. st. Warszawy, Akt urodzenia Marii Tekli Anny Trębickiej, par. św. Krzyża w Warszawie, 1830, nr 249 (z dn. 5 kwietnia 1830).

APW 1830 - Archiwum Państwowe m. st. Warszawy, Akt zgonu Stanisława Adama Trębickiego, par. św. Krzyża w Warszawie, 1830, nr 2102 (z dn. 31 listopada 1830).

APW 1833 - Archiwum Państwowe m. st. Warszawy, Akt małżeństwa Ludwika Trębickiego i Emilii Taszyckiej, par. św. Andrzeja w Warszawie, 1833, nr 42 (z dn. 14 lutego 1833).

APW 1858 - Archiwum Państwowe m. st. Warszawy, Akt zgonu Ludwika Trębickiego, par. św. Andrzeja w Warszawie, 1858, nr 518 (z dn. 17 września 1858).

\section{Wydawnictwa źródłowe i opracowania}

Architecture Funéraire 1871 - Architecture Funéraire Contemporaine. Spécimens de Tombeaux, Chapelles Funéraires, Mausolées, Sarcophages, Stèles, Pierres Tombales, Croix, etc. Choisis principalement dans les Cimetières de Paris, w: Bibliothèque de l'Architecte par Cèsar Daly. Sèrie des Ėtudes d'Architecture Contemporaine. Architecture Funéraire Contemporaine. Ducher et Cie, Ėditeurs, Paris 1871 .

BarbasiewiCz 2008 - Maria Barbasiewicz, Tradycja Mazowsza - powiat sokołowski. Przewodnik subiektywny, Warszawa 2008.

BARANOvSKIJ 1893 - Gavril V. Baranovskij, Ûbilejnyj sbornik svedenij o deâtel'nosti byvših vospitannikov Instuta graždanskih inženerov (Stroitel’nogo Učiliŝa), Sankt Peterburg 1893.

BARAnOvsKij 1902 - Gavril V. Baranovskij, Arhitekturnaâ ènciklopediâ vtoroj poloviny XIX veka, t. I, otd'l' 8, Sankt Peterburg 1902. 
Brzostek 2015 - Błażej Brzostek, Paryże innej Europy. Warszawa i Bukareszt, XIX i XX wiek, Warszawa 2015.

Co stychać? 1901 - Co stychać? Nowy kościót, „Zorza” 1901, nr 8, s. 188.

Dominikowski 2004 - Jan Dominikowski, Nekropolia Łodzi wielkoprzemysłowej. Cmentarz Stary przy ul. Ogrodowej. Dzieje i sztuka 1854-1945, Łódź 2004.

GILLE 2013 - Xavier Gille, Victor Ruprich-Robert Architecte (1820-1887), b.m., 2013.

GrochowsKa/STEFAŃski 2015 - Ewa Grochowska, Krzysztof Stefański, Kaplica grobowa rodziny Samsona Wollera w Leśnej koło Lubania - dzieło Carla Lüdeckego, „Architectus” 2015, nr 2, s. $31-40$.

JABŁOŃSKa 2003 - Teresa Jabłońska, Kaplica pałacowa pw. Zwiastowania NMP w Kozłówce, [w:] Lubartów i Ziemia Lubartowska, red. W. Śladkowski, Lubartów 2003, s. 29-37.

Kaplica rodziny Łojków 1866 - Kaplica rodziny Łojków (Na cmentarzu w Zakroczymiu), „Tygodnik Ilustrowany" 1866, nr 370, s. 196-197.

Kazimierz Trębicki (1895-1981), [w:] Słownik Biograficzny Polskiej Służy Zagranicznej 1918-1945, t. 5, oprac. K. Smolana, Warszawa 2013, s. 112-114.

Kronika. Uroczystość 1905 - Kronika. Uroczystość w Zembrowie, „Tygodnik Ilustrowany” 1905, nr 41, s. 764.

Kronika. Zmarli 1905 - Kronika. Zmarli, „Tygodnik Ilustrowany” 1905, nr 1, s. 18.

„Kurier Warszawski” 1905 - [Nekrolog Emilii z Trębickich, 1 voto Trębickiej, 2 voto Starzeńskiej], „Kurier Warszawski” 1905, nr 258, s. 5.

KZSP 1965 - Katalog Zabytków Sztuki w Polsce, t. X woj. warszawskie, red. I. Galicka i H. Sygietyńska, z. 25, pow. sokołowski, Warszawa 1965.

Les architectes 1907 - Les architectes élèves de l'école des Beaux-Arts 1793-1907, ed. E. Delaire et al., Paris 1907.

ŁOZA 1954 - Stanisław Łoza, Architekci i budowniczowie w Polsce, Warszawa 1954.

MAJDOWsKi 1991 - Andrzej Majdowski, Zarys systematyki architektury romańskiej w budownictwie kościelnym Królestwa Polskiego, „Nasza Przeszłość” 1991, t. 75, s. 117-137.

MajdowsKi 2011 - Andrzej Majdowski, Z dziejów fundacji sakralnych w Królestwie Polskim. Na marginesie budowy kościoła w warszawskiej parafii pw. św. Barbary, „Acta Universitatis Nicolai Copernici. Zabytkoznawstwo i konserwatorstwo” XLI, Toruń 2011, s. 75-107.

MARTY 1839 - Joseph Marty, Les principaux monuments funéraires du Père-Lachaise, de Montmarte, du Mont-Parnasse et autres cimetières de Paris, Paris 1839.

MinAKOwski 2013 - Marek Jerzy Minakowski, Elita podlaska. Elita Rzeczypospolitej, t. XV województwo podlaskie, Kraków 2013.

NiCiEJA 1998 - Stanisław S. Nicieja, Łyczaków - dzielnica za Styksem, Wrocław 1998.

NiCiEja 2011 - Stanisław S. Nicieja, Lwów. ogród snu i pamięci. Dzieje Cmentarza Eyczakowskiego oraz ludzi tam spoczywajacych w latach 1786-2010, Opole 2011.

Normand 1832 - Louis-Marie Normand, Monuments funéraires choisis dans les cimetières de Paris et des principales villes de France, Paris 1832.

Nowy kościót 1905 - Nowy kościót w Zembrowie, „Ziarno” 1905, nr 42, s. 308-309.

PietrZak 2002 - Marian Pietrzak, Kościoły i cmentarze ziemi sokołowskiej oraz duch i sny, Siedlce 2002.

Quaglia 1832 - Ferdinand Quaglia, Le Père Lachaise ou Recueil de dessins au trait et dans leurs justes proportions des principaux monumens de ce cimetière, Paris 1832.

RADŹWiCKA-MilCzewska 1994 - Anna Radźwicka-Milczewska, Akcja cmentarze: kaplica Braeunigów, „Spotkania z Zabytkami” 1994, nr 2, s. 45-46. 
TECHNE

T E X N H

SERIA NOWA

RUPRICH-Robert 1849 - Victor Ruprich-Robert, Tombeaux Taillepied de Bondy - Père Lachaise, «Revue Générale de l’Architecture» vol. 8, 1849, s. 164-166, pl. 33-36.

RUPRICH-ROBERT 1876 - Victor Ruprich-Robert, Chapelle funéraire Saint-Pierre au cimetière de Rânes (Orne), «Revue générale de l’architecture et des travaux publics» vol. XXXIII, 1876, n² 2, szp. 50-52, pl. 17-20.

Stefański 1992 - Krzysztof Stefański, Stary Cmentarz Ewangelicko-Augsburski w Łodzi, Łódź 1992.

SteFAŃSKI 1996 - Krzysztof Stefański, Kaplica-mauzoleum Karola Scheiblera w Łodzi - arcydzieło architektury neogotyckiej, „Miscellanea Łódzkie” 1996, nr 1(15), s. 50-53.

StefAŃSKi 2003 - Krzysztof Stefański, Kaplica grobowa Heinzlów w Łodzi a typ renesansowej kaplicy kopułowej $w$ architekturze epoki historyzmu, w: Recepcja renesansu w XIX i XX wieku. Materiały Sesji Stowarzyszenia Historyków Sztuki, Łódź, listopad 2002, red. M. Wróblewska Markiewicz, Łódź 2003, s. 361-378.

Stefański 2006 - Krzysztof Stefański, Kaplica grobowa Karola Scheiblera w Łodzi. Perła architektury neogotyckiej, Łódź 2006.

WiraszKa 2015 - Marta Wiraszka, Mauzoleum Prandotów Trzcińskich w Starej Rawie - pierwowzór i potencjalni twórcy, „Biuletyn Historii Sztuki” 2015, nr 3, s. 507-528.

WIRASZKA 2017 - Marta Wiraszka, Wykorzystanie publikacji francuskich przy realizacji nagrobków na cmentarzach Warszawy w latach 1840-1860. Wzorniki Normanda i Quaglia, „Artifex Novus” 2017, nr 1, s. 44-59.

WIRASZKA 2018 - Marta Wiraszka, Wykorzystanie publikacji francuskich przy realizacji nagrobków na cmentarzach Warszawy w latach 1840-1860. Wzornik Josepha Marty'ego, „Saeculum Christianum" 2018, t. XXV, s. 284-311.

WIRASZKa 2019 - Marta Wiraszka, Kaplice i mauzolea na cmentarzach Warszawy w XIX i pierwszej połowie XX wieku, t. 2: Źródła inspiracji, Warszawa 2019.

Zembrów 1895 - Zembrów, [w:] Stownik geograficzny Królestwa Polskiego i innych krajów stowiańskich, red. B. Chlebowski, t. XIV, Warszawa 1895, s. 570.

ŻABICKI 2010 - Jacek Żabicki, Leksykon zabytków architektury Mazowsza i Podlasia, Warszawa 2010. 


\section{The tomb chapel of the Trębicki family in Zembrów as an example of French influences in the $19^{\text {th }}$ century sepulchral construction in Poland}

$\mathrm{T}$ he chapel of the Trębicki family (Ślepowron coat of arms), was built in 1884 in the old church cemetery in Zembrów in Podlasie (Sokołów district). The building was erected by Stanisław and Emilia Trębicki, owners of the estate and the brick manor in Kurowice. The architect, unknown by name, gave the chapel made of cherry colored bricks and gray sandstone Romanesque-Gothic forms, which he borrowed from the French trade journal "Revue générale de l'architecture et des travaux publics". The prototype were the plans for the burial building of the aristocratic Berghes family, which was designed and erected in the cemetery in Rânes (Normandy region, Orne department) in 1872-1873 by architect Victor Ruprich-Robert (1820-1887), published in its pages in 1876. The chapel in Zembrów is one of the many Polish tombs inspired by French implementations. The research conducted by the author so far has shown that statistically the largest number of such objects were created in Catholic cemeteries in Warsaw (33) and in the Kingdom of Poland (9).

Keywords: Zembrów, Trębicki chapel, Polish sepulcral architekturę, French sepulcral architecture 